\title{
In the Wake of Rubin "Hurricane" Carter:
}

The Plight of John Artis

\section{By Rebekah Spaulding}

\section{DOI: http://dx.doi.org/10.14713/njs.v2i2.48}

In the summer of 1966 in Paterson, New Jersey, Rubin "Hurricane” Carter and John Artis were arrested on suspicion of triple homicide. Tried and convicted the following year, Carter and Artis would spend almost twenty years in jail, despite evidence of witness tampering and police malfeasance. During and after their incarceration, Carter received an abundance of public support due to his famous boxing career, while Artis often went unnoticed as a secondary character by the media. By examining the details surrounding Carter and Artis's wrongful imprisonment, it is clear to see the institutional racism and systematic criminalization of African Americans, as well as the impact of notoriety in criminal justice. While this case is undoubtedly a gross miscarriage of justice, it is the forgotten story of John Artis that shows the flaws of the criminal justice system and how society is told to remember its history.

On June 17, 1966 in Paterson, New Jersey, the doors to the Lafayette Bar and Grill opened to reveal two men armed with a rifle and a revolver. These men proceeded to shoot the bartender and the three remaining patrons who were waiting for last call that late evening. The bartender and another patron died on the spot, while the other two were rushed to the hospital (one later died). Witnesses on the street could not positively identify the perpetrators as they fled the scene; the only description provided was that of two fair-skinned African Americans, about the same height, driving away in a white sedan. Across town, the police picked up Rubin "Hurricane" Carter, a local boxing celebrity, and John Artis, a recent high school graduate, who were leaving a different bar. Both African American and driving a white car, they fit the general description provided, and 
the police brought them in for questioning. They eventually released Carter and Artis after a long interrogation. Four months later, a "mystery witness" came forward and placed Carter at the scene, accusing him of killing three of the people who were in the bar that night. Unable to discount that there were two suspects involved, the police arrested both Carter and Artis and the Passaic County Criminal Court of New Jersey tried and convicted them in May 1967 of triple homicide.

A unique national campaign to free Rubin Carter from his wrongful conviction followed. Though Artis was arrested and imprisoned for the same crime, Carter, a successful boxer, was better known and received nearly all of the public sympathy in the controversial case. Numerous campaigns by other athletes and celebrities emerged in the decade following his conviction, raising money and awareness for Carter's (and by default Artis's) acquittal. What makes this case and the effort to free these two men significant is that even though there were two defendants here, only one was receiving national attention, and therefore, direct help. This help primarily came in the form of numerous defense funds financed by celebrities and others who championed Carter's cause- despite the fact that Carter had a history of violence and criminal activity in Paterson, while Artis had no such background.

Not only had two men been arrested without a motive and with solid alibis, there was an institutional understanding in the justice system that arresting these men was for the betterment of the town, regardless of the lack of any direct evidence to place them at the crime scene. While Carter did have prior convictions, Artis had no criminal background, making him more the victim of assumed black criminality. Though Carter was the main target of the case, as evidenced by the mystery witness and subsequent witnesses placing only Carter at the scene, the police accepted that Artis would be collateral damage. Carter was definitely a victim of police malfeasance, but he was the one who had the attention of the police and who garnered the support of the public, while 
Artis was included simply because he was in the wrong place at the wrong time. While the case revolving around Rubin "Hurricane" Carter was undoubtedly a perversion of justice, history has failed to recognize John Artis as the "bigger victim." The forgotten story of John Artis, far more than the well-known story of Rubin Carter, demonstrates the tragedy of assumed black criminality in the justice system in the mid- to late twentieth century.

\section{Contextualizing the Case}

In Carter and Artis's lifetimes, there were many advances in the civil rights movement, including Brown v. Board of Education in 1954 and the signing of civil rights legislation. The period also saw civil rights marches all over the country devolve into violence and the assassinations of President Kennedy, Malcolm X, Dr. Martin Luther King, and Robert Kennedy, all outspoken figures in favor of equality in the United States. The case, in the context of the times, could not escape the realities of racial bias and the long-term effects of criminal racial inequality in the United States. The concept of black criminality was still influential in many court systems in the 1960s and 1970s, and Artis was a victim of this theory. The prevalent theory of black criminality purported a statistical correlation between race and crime in the twentieth century; specifically asserting that African Americans were more likely to commit crimes, regardless of their upbringing, education, and other factors that define a person. Black criminality attributes a proclivity to criminal behavior as one of the most defining factors of the African American race. When the Federal Bureau of Investigation began collecting arrest statistics in the 1930s, categories of offenders reflected whites, blacks, and foreign-born immigrants. By 1941, however, the category for immigrants all but disappeared into the "white" category, leaving statistics which indicated offenders arrested were either white or black. Immigrants became "decriminalized" by their inclusion in the white category, leaving blacks unprotected by the justice system such that 
"Blackness now stood as the singular mark of a criminal." Because these statistics seemed to show a correlation between race and proclivity to crime, in addition to institutional acceptance of black criminality, police officers focused their efforts on black communities. An increased police presence then led to increased arrests of blacks, reinforcing notions of black criminality and supposedly preventing any future crimes likely to be committed by these individuals. ${ }^{2}$ According to Khalil Gibran Muhammad, "African American criminality became one of the most widely accepted bases for justifying prejudicial thinking, discriminatory treatment, and/or acceptance of racial violence as an instrument of public safety." It is clear that both Carter and Artis were victims of this theory, but because Artis had no actual criminal background and had no reason to be considered involved in criminal behavior, he is the bigger victim.

Black criminality was also a defining theory in urban America, in towns like Paterson, New Jersey, for instance. African Americans in urban areas in the northern part of the country had difficulty escaping the stigma of criminality because there was more poverty, more potential for violence and race riots, and an ever-increasing population. ${ }^{4}$ Paterson was no different, even though its population was smaller than other urban areas. Poverty lines prevented Paterson from developing into an industrial city, and there was a significant split in the population in terms of ethnic groups, allowing for dissenting movements of the citizenry throughout the area. There were even "rumors of an unholy alliance of police, politicians, and organized crime," all lending themselves to the furtherance of inequality and corruption in the justice system. ${ }^{5}$ By combining

\footnotetext{
${ }^{1}$ Khalil Gibran Muhammad, The Condemnation of Blackness: Race, Crime, and the Making of Modern Urban America (Cambridge, Massachusetts: Harvard University Press, 2010), 270-271, 273-274.

2 Muhammad, Condemnation of Blackness, 4-7.

${ }^{3}$ Ibid., 4.

${ }^{4}$ Ibid., 11.

5 Paul B. Wice, Rubin "Hurricane” Carter and the American Justice System, (New Brunswick, NJ: Rutgers University Press, 2000) 19.
} 
the theory of black criminality with the reality of institutional racism in the justice system, "criminal justice became increasingly about the management of urban black populations," instead of the prevention of any criminal activity in the urban areas. ${ }^{6}$ The acceptance of black criminality was the reality in many urban towns across the country, but it was in Paterson that the enforcement of this theory by the justice system resulted in the wrongful imprisonment of Carter and Artis.

\section{Background Information}

The backgrounds of both Carter and Artis also play a crucial role in understanding the case and the argument that Artis was the bigger victim. John Artis was born in 1946, and moved to Paterson, New Jersey at a very young age. He attended church regularly with his family and sang in the choir every Sunday. In high school, he was a successful two-sport athlete and was even presented with the opportunity to run track in college on a scholarship. However, while he was considering whether to go to college or enlist in the Army, his mother passed away. He took a year off after graduation and worked many odd jobs in Paterson. At the time of his arrest, he had no prior criminal record and was only nineteen years old. Not much else can be said of Artis's background because he stayed out of trouble and out of the papers until he became affiliated with Rubin Carter in $1966 .^{7}$

Artis's early life differs greatly from Carter's. ${ }^{8}$ Carter was born in 1937 in Passaic County, New Jersey and moved to Paterson when he was seven years old. According to Carter, he and his siblings were abused from an early age. ${ }^{9}$ Carter joined the local gang, putting himself into possible

\footnotetext{
${ }^{6}$ William J. Stuntz, The Collapse of American Criminal Justice (Cambridge, Massachusetts: Harvard University Press, 2011), 249.

${ }^{7}$ Wice, Rubin, 38.

${ }^{8}$ The available scholarship on Carter all references Carter's own autobiography in order to detail and understand his background. Rather than using secondary sources, which cite Carter, the author chose to utilize his autobiographies first hand. The author has attempted to use only relevant and factual claims, however, as autobiographies obviously have inherent and unavoidable biases.

${ }^{9}$ Rubin Carter, The Sixteenth Round: From Number 1 Contender to \#45472 (New York: The Viking Press, 1974$), 4$.
} 
criminal situations. His first run-in with the law occurred when an estimated twenty members of the gang were arrested and given two years' probation for stealing clothes from a department store. ${ }^{10}$ In 1948, Carter and some of his gang friends were walking on the banks on the top side of the Passaic Waterfalls when an older white man who appeared drunk tried to force himself onto one of Carter's friends. Carter, having a history of getting into fights and defending those around him, threw a bottle at the old man's head, and it struck him. The old man left Carter's friend and instead came after Carter. The man grabbed Carter and attempted to throw him off the bank. Carter had a small scout knife in his possession and he stabbed the man in order to get away. He ran home, leaving the man behind. A few days later, Carter was arrested for stabbing the man and was sent to the Jamesburg State Home for Boys. He was just eleven years old. ${ }^{11}$

In 1954, Carter managed to escape from the Jamesburg State Home for Boys and quietly made his way to his aunt's house in Philadelphia. There, he enlisted in the United States Army in the hopes of becoming a paratrooper. ${ }^{12}$ While stationed in Germany, he started boxing and won at least $\$ 6,000$ from his matches. Carter might have qualified for the Olympics if he re-enlisted, but he chose not to and was discharged from the Army in June 1956. He returned to Paterson shortly after his discharge. On July 4, 1956, he was arrested for escaping from Jamesburg. He was taken to Annandale Reformatory to finish out the time he was meant to have spent at the Jamesburg State Home for Boys. ${ }^{13}$ Ten months later, he was released, and he returned to Paterson. He reconnected with one of the friends he made while in the Jamesburg State Home for Boys. Together they mugged three different people in broad daylight. Carter was soon arrested for the muggings, and

\footnotetext{
${ }^{10}$ Carter, The Sixteenth Round, 16, 25.

11 Ibid., 29-41.

${ }^{12}$ Carter, Rubin Carter, Eye of the Hurricane: My Path from Darkness to Freedom (Chicago: Lawrence Hill Books, 2011), 35.

${ }^{13}$ Carter, The Sixteenth Round, 137-141.
} 
in August 1957 he was sentenced to nine years in Trenton State Prison. ${ }^{14}$ There, he trained his body and mind, pledging to stay out of prison and out of Paterson after his release. He hoped to become a professional boxer. In September 1961, Carter was released and continued his training to be a world champion prize fighter. ${ }^{15}$

It was his style of fighting that gave Carter his nickname, "The Hurricane." Though he lacked the standard boxer's body, standing at only five foot eight inches tall and weighing in at one hundred and fifty pounds, he was often compared to Sonny Liston, a successful heavyweight boxer who fought with the same fury and intensity. In his first fight at Madison Square Garden, it took Carter only sixty-nine seconds to knock out his opponent, Florentino Fernandez. Within his first two years of professional boxing, he knocked out forty-seven of his opponents. ${ }^{16}$ Carter took on the middleweight champion in December 1964, but he could not beat the veteran favorite. ${ }^{17} \mathrm{He}$ was arrested again in Paterson for starting a fight in 1964 and for gambling in 1965, but was eventually released on bail both times. He continued fighting, traveling as far as South Africa to do so. By 1966, however, he was willing to take a break from his job, and settled down with his wife and daughter in Paterson.

\section{Artis and Carter Under Fire}

Though Artis and Carter led very different lives, they were both leaving the Nite Spot, a nightclub in Paterson, at the same time on June 17, 1966. They decided to leave together, as they were heading home in the same direction. Another man, John "Bucks" Royster, also hopped in the white car for a ride home. While driving to Royster's home, Artis, who was driving, was pulled

\footnotetext{
${ }^{14}$ Ibid., 156-159.

15 Ibid., 183-185.

${ }^{16}$ Leonard Shecter, "The Baleful Look of a New Liston," Sports Illustrated, October 14, 1963, http://sportsillustrated.cnn.com/vault/article/magazine/MAG1075263/4/index.htm.

17 “Giardello Choice Over Hurricane,” Los Angeles Times, December 14, 1964, http://search.proquest.com.mutex.gmu.edu/docview/155092924?accountid=14541.
} 
over by Sergeant Capter, who quickly recognized Carter in the back seat. They were informed that there was an alarm out for "a white car with two Negroes in it," but they obviously did not fit the bill as there were three people in their car. ${ }^{18}$ Sergeant Capter let them go, and Artis drove Royster home. They then were pulled over again, this time fitting the description of the alarm. Carter and Artis were convoyed to Lafayette Bar and Grill, nearly twelve blocks away, where the shooting had taken place. They surveyed the scene and then were rushed to the hospital, where the two survivors were receiving treatment for their gun shot wounds. There, the police officers, including Sergeant Capter, asked the injured man if he recognized Carter and Artis as the men who shot him. He shook his head "no," but Carter and Artis were taken to the police station to be interrogated shortly thereafter. ${ }^{19}$ While at the station, they were interrogated, placed in a police lineup, and subjected to a polygraph test. No one identified them in the lineup, and they both passed their polygraphs. The police eventually let them go after many hours in custody. ${ }^{20}$

By October, the third victim had died from injuries sustained that night, and the police were struggling to find any leads on the suspects. However, a "mystery witness" had come forward, naming Carter as one of the men who fired upon the patrons in Lafayette Bar. On October 14, 1966, the police arrested both Artis and Carter for triple murder as a result of the mystery witness' testimony to the police. ${ }^{21}$ The police reasoned that because there were two suspects for the homicide, and Carter was last seen with Artis, then Artis must be guilty as well. There was no case against Artis without Carter. This is the first sign of Artis as the "bigger victim." No one accused him of murder, but he was implicated in the crime simply because he was with Carter that night.

\footnotetext{
${ }^{18}$ Carter, The Sixteenth Round, 243.

19 Ibid., 2.

${ }^{20}$ Ibid., 243-251.

21 “Boxer Rubin Carter Held in Murders," Boston Globe, October 16, 1966, http://search.proquest.com.mutex.gmu.edu/docview/366975055?accountid=14541.
} 
Eventually, evidence would come to light that Carter was identified by Alfred Bello and Arthur Dexter Bradley, two white men who happened to be robbing a factory up the street from the bar the night of the shooting. After hearing the shots, Bello claimed he ran into the bar, saw the carnage, and decided to rob the register. The third witness, Patty Valentine (who lived above the establishment), encountered Alfred Bello in the bar. Bello instructed Valentine to call the police, and she did so. It was these combined testimonies that placed Carter at the scene, even though 1., Valentine only claimed to have seen two African Americans driving away when she looked from her second floor window, 2., Bradley was robbing a factory up the street, and 3., Bello was acting as lookout (one who ended up robbing the bar itself). It is possible that Bello and Bradley may have been the actual perpetrators, as they had a history of criminal offenses and were obviously at the bar around the time of the murders, but they were never considered. Because their alibi was that they were in the process of robbing the factory up the street, they were able to strike a deal with the police by providing them with the names of the murder suspects in exchange for leniency in their robbery cases.

It took three weeks for a jury to be selected. Because of the extensive press coverage the town had been receiving for nearly six months, it was difficult to find jurors without any prior knowledge of the case. Eventually, the final jury included ten men and four women. ${ }^{22}$ New Jersey court rules require fourteen jurors to hear a case in its entirety, and then two jurors are selected by lottery to be alternates before deliberation. In this case, only one of the jurors was African American, and he would subsequently be excluded from deliberations as a result of the lottery process. When the case finally began, Bello, Bradley, and Valentine all testified against Carter and Artis. The lawyers for Carter and Artis worked together because the two men allegedly participated

\footnotetext{
${ }^{22}$ Wice, Rubin, 46.
} 
in the same crime. In this first case, there were no indications that Artis's lawyer, Arnold Stein, attempted to ask for a severance, where Carter and Artis could be tried separately. In fact, Stein rarely took the floor in this trial, allowing Carter's high-priced, shrewd defense attorney, Raymond Brown, to take the lead. ${ }^{23}$ Carter and Artis both testified, declaring their innocence. They had never even been in the Lafayette Bar and Grill before they had been brought there the night in question. ${ }^{24}$ In closing arguments, Brown and Stein offered many reasons for Carter and Artis's innocence, including their alibis, and the fact that the prosecution's main witnesses, Bello and Bradley, lacked credibility because they were known criminals in the town of Paterson. Despite these arguments, on May 25, 1967, Carter and Artis were found guilty. ${ }^{25}$ Carter was sentenced to two consecutive life terms, which was argued down from three terms during sentencing. Artis, with his exemplary record and clean background, received "one life sentence with the other two to run concurrently."26 While in prison, Artis was the model prisoner. He took classes and stayed out of trouble, biding his time until eligible for parole. At the same time, Carter worked on appeals, trying to clear his name. A publicity campaign sprang forth for Carter, especially after the autobiography he wrote while in prison was published in 1974. In particular, a New York Times reporter, Selwyn Raab, would uncover facts indicating that Bello and Bradley's testimonies were falsified and obtained through unscrupulous means. It would later be revealed that police bribed Bello and Bradley with reward money and leniency if they placed Carter at the scene. In 1974, Raab was able to locate Bradley and Bello and record their recantations on the front page of the New York Times. Raab reported a shoddy police investigation and evidence of pressure placed on Bello and Bradley to identify Carter as one of the suspects. Bello stated he was told to take the reward money and leave

\footnotetext{
${ }^{23}$ Ibid., 45.

${ }^{24}$ Ibid., 59-60.

${ }^{25}$ Ibid., 64-65.

${ }^{26}$ Ibid., 65.
} 
town before the initial trial. They both admitted to being motivated by the money, in addition to leniency, for their statements, which had only indicated that they just saw two unidentifiable African Americans drive away, not Carter or Artis. ${ }^{27}$ After the initial judge denied a new case, Carter attempted to take his case to a higher court.

Raab introduced Carter to a New York attorney, Myron Beldock, who had experience with cases similar to this one. Artis acquired a new lawyer from New York as well, Lewis Steel, who specialized in civil rights cases. Beldock and Steel argued the initial judge was biased and partisan in the original case, but were unsuccessful in convincing the judge to remove himself. Because of this, the initial judge would be the one to decide if the appeal would reach the State supreme court. Beldock and Steel were subsequently able to present the recantations, as well as some evidence that had been excluded from the first trial. ${ }^{28}$ On November 6, 1975, the New Jersey Supreme Court announced they would hear the new case. On March 18, 1976, in a unanimous decision, Artis and Carter earned a new trial. ${ }^{29}$

In the new trial, finding credible witnesses for the defense was difficult, due to possible pressure by the Paterson police. Bradley was left off the prosecution's witness list because he was deemed an inadequate witness due to his criminal background. However, Bello would testify, recanting his original testimony. ${ }^{30}$ Knowing that the recantations and the new evidence were going to be a big obstacle for the prosecution, the State came up with a motive for the murders, an element missing from the original trial. The lead prosecutor, Burrell Humphreys, presented a "racial revenge" theory as motive. The same day as the triple homicide, an African American bar owner

\footnotetext{
${ }^{27}$ Selwyn Raab, "Murder Case Witnesses Recant 7 Years After 2 Got Life Terms," New York Times, September 27, 1974 http://search.proquest.com.mutex.gmu.edu/docview/119987906?accountid=14541.

${ }^{28}$ Selwyn Raab, "Same Judge Gets Carter's Appeal,” New York Times, January 31, 1975, http://search.proquest.com.mutex.gmu.edu/docview/120332491?accountid=14541.

${ }^{29}$ Selwyn Raab, "Rubin Carter and Artis Get New Trial in Murder Case," New York Times, March 18, 1976, http://search.proquest.com.mutex.gmu.edu/docview/122965313?accountid=14541.

${ }^{30}$ Wice, Rubin, 120.
} 
had been killed by a white man. According to the prosecution, Carter wanted to avenge the black bar owner's death by shooting and killing white victims in a different bar, and it just so happened that Artis was dragged along with him. ${ }^{31}$ It should be noted that even to the prosecution, Artis was along for the ride, not complicit in any wrong doing, but as stated before, in order to get Carter, there had to be a second man: Artis. The bartender's son-in-law testified, however, that he had never discussed his father-in-law's murder with Carter and he had never even seen Artis that night. $^{32}$

After the prosecution rested its case-in-chief, the defense moved to drop the charges. Lewis Steel took this opportunity to point out that Artis had never been directly identified at the scene during the trials. The judge was sympathetic and said that if he had been the original trial judge he might have ordered a severance of the case, allowing for separate trials for Artis and Carter, but there was nothing he could do at that point in the proceedings. ${ }^{33}$ The defense had to continue, then, and presented the jury with new alibi witnesses, as well as Selwyn Raab, the reporter who championed Carter's case. Unlike the first case, only Artis testified this time. He calmly denied any involvement in the murders, saying that he and Carter were only acquaintances at the time of the arrest, and that he had never fired a gun in his life. ${ }^{34}$ Though the defense had been cautiously optimistic, especially in light of the new evidence and witness testimonies, Carter and Artis were again found guilty on December 22, 1976. Each man was given their original sentences to fulfill. ${ }^{35}$ Carter and Beldock would continue to work on appeals from prison, but, as before, they were unable to find a judge who was willing to hear their case. In 1983, however, the files from

\footnotetext{
${ }^{31}$ Ibid., 129.

32 Ibid., 131.

${ }^{33}$ Ibid., 133-134.

${ }^{34}$ Leslie Maitland, “Artis Goes On Stand But Carter Decides He Will Not Testify,” New York Times Dec. 16, 1976, http://search.proquest.com.mutex.gmu.edu/docview/122986029?accountid=14541.

${ }^{35}$ Wice, Rubin, 144.
} 
one of the outside investigators came to light, revealing a number of new aspects to the case that could establish Carter and Artis's innocence. These files included suppressed evidence, including new witnesses that had been with Valentine that night, as well as evidence that the 911 call that reported the incident had been altered. ${ }^{36}$

In November 1984, Carter, Beldock, and an appellate expert, Leon Friedman, came up with a plan to present their new evidence without having to face the same judge who had been denying their appeals. Eventually, the case made its way to a higher judicial authority and was heard by Judge Lee Sarokin. The defense, at this time, filed a writ of habeas $\operatorname{corpus}^{37}$ with the federal court and was forced to make a choice. Because they went around all state options, they had to choose between going backwards to the local court or filing a motion for summary judgment. A summary judgment "meant that their issues were so clear and persuasive that there would be no need for laborious and time-consuming hearings." 38 They filed for summary judgment, knowing that this was perhaps their last chance to overturn the verdict. The judge would decide the case on the merits of the briefs and oral arguments from the defense only.

Oral arguments began on July 26, 1985. Defense argued that the racial revenge theory as motive violated Carter and Artis's Fourteenth Amendment rights, as there was no evidence of racial hatred from Carter or Artis, and no reason for the Lafayette Bar to be targeted, as it was a racially-mixed bar. The numerous occasions of prosecutorial misconduct were also included. Once again, the defense felt optimistic. ${ }^{39}$

\footnotetext{
${ }^{36}$ Ibid., 166.

${ }^{37}$ Ibid., 179. According to Wice, "a writ of habeas corpus simply means court proceedings to be held in order to discharge a prisoner in unlawful custody."

${ }^{38}$ Ibid., 181.

${ }^{39}$ Ibid., 180-182.
} 
On November 17, 1985, Judge Sarokin made his decision. He ruled in favor of the defense, stating,

The extensive record clearly demonstrates that petitioners' convictions were predicated upon an appeal to racism rather than reason, and concealment rather than disclosure... The jury was permitted to draw inferences of guilt based solely upon the race of the petitioners but yet was denied information which would have supported their claim of innocence. ${ }^{40}$

The prosecution looked for appeals over the next year and a half, but in August 1987 Judge Sarokin's decision was upheld by a unanimous circuit court decision. ${ }^{41}$ The triple homicide at the Lafayette Bar and Grill remains unsolved to this day.

\section{Where We Go from Here}

Though Carter and Artis were free men, neither of them continued their lives as they had before. Throughout his imprisonment, Artis had been a model prisoner, taking college courses at Glassboro State. When he appeared for his parole hearing in December 1981, he had been set free. ${ }^{42}$ Unfortunately, while in prison, he had contracted Beurger's Disease, a rare disease of his arteries and veins which necessitated amputation of several fingers and toes. ${ }^{43}$ In addition to this bad fortune, Artis was arrested in April 1986 in Passaic County for conspiracy to distribute cocaine after having been found with cocaine, drug paraphernalia, and a stolen weapon in his possession. ${ }^{44}$ Very little can be found in the press about Artis following his upheld exoneration in 1987, but Selwyn Raab did report in 1988 that Artis and his lawyer were attempting to get his maximum sixyear sentence for his 1986 conviction reduced. His initial sentence for the drug charges had been

\footnotetext{
${ }^{40}$ Carter v. Rafferty. 621 F. Supp. 533 (D.N.J. 1985).

${ }^{41}$ Carter v. Rafferty. 826 F.2d 1299 (3d Cir. 1987).

${ }^{42}$ Wice, Rubin, 163.

${ }^{43}$ Ibid., 38, 39.

${ }^{44}$ Wolfgang Saxon, “Artis, Co-defendant with Rubin Carter, Held on Drug Charge,” New York Times, April 21, 1986, http://search.proquest.com.mutex.gmu.edu/docview/110943166?accountid=14541.
} 
made under the assumption that he was guilty of triple homicide. Once that decision was overturned, his sentence was ultimately reduced. ${ }^{45}$

Carter would move to Canada and eventually became chairman of the Association in Defense of the Wrongly Convicted. His life outside of the prison system was not as troubled as Artis's. As recently as 2013, both Carter and Artis traveled the world lecturing on behalf of victims' rights and innocence initiatives. ${ }^{46}$ Upon Carter's death in April 2014, his story was once again brought to light, and Artis's involvement in the difficult chapter of the boxer's life was yet again missing from the posthumous examination of the case. In the New York Times obituary written for Carter, Artis is simply described by longtime Carter journalist, Selwyn Raab, as a "friend and onetime co-defendant" to the famed prize fighter. ${ }^{47}$ While Carter and Artis did travel together and stayed close following their exoneration, Artis's side of the story of their initial connection remains relegated to the sidelines of any media coverage of the boxer, including that which followed his passing. ${ }^{48}$ Carter's fame continues to overshadow the tragedy of Artis's wrongful conviction.

Carter's fame and history in Paterson played significant roles throughout the case. It was Carter who rallied popular support, not Artis. Not only was Carter a successful boxer, but he had famous friends who were willing to stand up for him. Defense funds were set up in his name, including the "Hurricane Defense Fund" and the "Hurricane Trust Fund," and celebrities were

\footnotetext{
${ }^{45}$ Selwyn Raab, "Court Orders a New Hearing on Reducing Artis Sentence," New York Times, June 15, 1988, http://search.proquest.com.mutex.gum.edu/docview/110526123? accountid=14541.

46 "Carter dying of cancer," The Sunday Mail (Queensland, Australia), March 11, 2012 http://www.lexisnexis.com.mutex.gmu.edu/hottopics/lnacademic/.

${ }^{47}$ Selwyn Raab, "Rubin (Hurricane) Carter, Twice Wrongly Convicted of Murder, Dies at 76," New York Times, Apr 21, 2014, Late Edition (East Coast), http://search.proquest.com.argo.library.okstate.edu/docview/1517859806?accountid=4117.

48 "Boxer Rubin 'Hurricane' Carter Dies at 76 (Posted 2014-04-21 03:57:11)," The Washington Post, Apr 21, 2014, http://search.proquest.com.argo.library.okstate.edu/docview/1518098133?accountid=4117.
} 
constantly on a mission to support Carter. ${ }^{49}$ Boxer Muhammad Ali and actress Ellen Burstyn, after organizing a rally in Trenton, even met with then-governor Brendan Byrne in order to request clemency for Carter (and Artis) while they awaited their second trial. ${ }^{50}$ Clemency was indeed granted as a result of this meeting. Even famed singer Bob Dylan had been in contact with Carter and would in 1975 pen one of his famous protest ballads in support of him. Dylan would play "Hurricane" in front of thousands of people, and standing on the stage with him were often other prominent artists of the time like Ringo Starr and Joni Mitchell. ${ }^{51}$ While there are other inconsistencies in Dylan's song, the most glaring absence is that of any mention of John Artis. ${ }^{52}$

An examination of the national newspaper coverage of this case makes clear that Artis often received second billing to Carter. Most articles do not even include Artis's name in the headline, and if they do, it is always "Carter and Artis," never "Artis and Carter." Carter, after all, was the famous boxer, and even in the articles about Artis's arrest for drug charges, the story always links him back to Carter. The national campaigns put on by the public often forgot Artis as well, as seen simply in the names "Hurricane Defense Fund," and "Hurricane Trust Fund." Although the money raised for Carter's defense ultimately helped Artis afford his lawyer, the money was never in his name. It should also be noted that Carter himself rarely discussed Artis in his first or his second autobiography, written in 1974 and 2011, respectively.

In more recent history, it is perhaps the most disheartening that in the 1999 major motion picture, The Hurricane, Artis is depicted in scenes leading up to and during the initial arrest, and

\footnotetext{
49 “Group Seeks New Trial for Carter,” New York Times, September 1, 1975, http://search.proquest.com.mutex.gmu.edu/docview/120648447?accountid=14541. 50 “Ali Joins Fight for Rubin Carter," Chicago Defender, October 21, 1975, http://search.proquest.com.mutex.gmu.edu/docview/494147822?accountid=14541.

${ }^{51}$ Larry Rohter, "Dylan to Bat for Carter," The Washington Post, January 22, 1976, http://search.proquest.com.mutex.gmu.edu/docview/146476375?accountid=14541.

52 "Bob Dylan - Hurricane lyrics," accessed April 1, 2013, http://www.metrolyrics.com/hurricane-lyrics-bobdylan.html.
} 
at no other points in the film. ${ }^{53}$ Similar to Dylan's song, there are a number of inconsistencies in the movie, including an incorrect depiction of one detective being "out to get" Carter, as well as any evidence of Carter's numerous stints in prison prior to the murder arrest. For both the song and the movie, it is understandable to use artistic license to tell a more dramatic story or to make the words rhyme in a certain way, but to leave out John Artis is a gross oversight. Removing Artis from the narrative in the film and the Dylan song indicates that the only victim in this case was Carter. Note that the movie was based on a book written by two men who helped the investigation leading to the final acquittal in 1985. The book includes plenty of references to Artis, but these references were not included in the film. ${ }^{54}$ Artis's absence from popular narratives might leave many believing Carter was the only victim wrongly accused in the case.

\section{Conclusion}

Utilizing a variety of primary and secondary sources, this paper shows that John Artis was a bigger victim of the theory of black criminality than Carter. It is very difficult to find any information on Artis without being overwhelmed by information on Carter. Very few interviews have been conducted and documented with Artis, and only rarely was he quoted in the newspaper coverage following the case. It is unknown whether Artis asked to be excluded from the 1999 film (as he did not respond to this author's request for an interview). Removing himself from the film would indeed explain the singular focus on Carter as the main character, but it is difficult to imagine Artis requesting this given the fact that Artis toured the world with Carter speaking out for victims' rights. Perhaps Artis asked Bob Dylan to exclude him from his song as well, though there is no evidence of this. It is difficult to understand what Artis might have been thinking during

\footnotetext{
${ }^{53}$ The Hurricane, performed by Denzel Washington (Universal City, California: Universal Studios, 1999), DVD. ${ }^{54}$ Sam Chaiton and Terry Swinton, Lazarus and the Hurricane: The Freeing of Rubin "Hurricane" Carter (New York: St. Martin's Griffin, 1991).
} 
his imprisonment and the decades following. Though Carter was the face of their case, Artis still benefitted from his celebrity. Though he was the bigger victim, he was able to gain assistance from the support given to Carter. It is possible that Artis has himself accepted his position in Carter's life, and we may simply never hear the full side of his story or reap the benefits from understanding his experiences.

Ultimately, the fact that Artis has been forgotten by the media and in popular culture is not the most tragic aspect of this case. What is devastating is that Artis was a victim simply because he, with Carter, fit the description given at the scene that late summer night in 1966 . He was just nineteen years old, had no criminal background, had no motive, and had no reason to be at that bar. When Carter was accused of the crime, Artis was automatically thrust into complicity based on the color of his skin and his association with Carter. Both Carter and Artis were victims of the Paterson police's need to solve their case quickly, so they found an easy target; that is undeniable. Black criminality was in play here because it was assumed that having a violent past almost automatically resulted in recidivism (in Carter's case). If the police were wrong to arrest Carter for the bar shooting, at least they were keeping this violent criminal off the streets. Artis, more so, was a victim of this theory. Because it was believed that African Americans had a predisposition to commit crimes, it did not matter that Artis had no criminal past. Because he was black, it was acceptable to believe he might be violent in the future. Instead of using prison as a rehabilitative measure, the court system in this case, in order to satisfactorily convict Artis along with Carter, essentially allowed for prison to become a preventative measure. Artis had become acceptable collateral damage to the police and to the prosecution. Because there was no way to separate Carter and Artis, Artis, too, must be guilty. He could not escape the color of his skin or his association with Carter. He remains a victim of history, forgotten in favor of celebrity and simplicity. With 
any luck, however, we can use this case and its role in our narrative to remember that for every Rubin Carter, there is a John Artis, waiting to have his story told.

Rebekah Spaulding, native of Stillwater, Oklahoma, completed her Bachelor of Arts in History from Oklahoma State University in 2012. In 2014, she completed her Master of Arts degree in History from George Mason University, where she studied the cultural and political changes of the United States in the twentieth century. Spaulding returned to Oklahoma State to earn her MBA degree in 2016. She volunteers as an editor for the Oklahoma Oral History Research Project and is pursuing a career in higher education and non-profit development. 